\title{
Modal Sosial Untuk Meningkatkan Pengetahuan Dan Kepedulian Pemuda Dalam Pembangunan Perdesaan Di Desa Gondang
}

\author{
Maya Atri Komalasari*, Lalu Wiresapta Karyadi, Dwi Setiawan Chaniago, \\ Oryza Pneumatica Inderasari
}

Program Studi Sosiologi Universitas Mataram, Mataram, Indonesia;

\section{Kata Kunci: \\ Modal Sosial, \\ Pemuda, \\ Pembangunan \\ Perdesaan}

\begin{abstract}
Abstrak:
Program pengabdian masyarakat ini bertujuan untuk meningkatkan pengetahuan dan kepedulian pemuda terhadap berbagai potensi desa. Sosialisasi mengenai modal sosial dilakukan pada para pemuda di Desa Gondang, Kecamatan Gangga, Kabupaten Lombok Utara. Sosialisasi diawali dengan memaparkan modal sosial dan kegunaannya dalam berbagai aspek bidang kehidupan. Sosialiasi juga memberikan gambaran dan contoh penerapan modal sosial yang dilakukan pemuda dalam pembangunan perdesaan. Sosialisasi mengenai modal sosial sebagai program pengabdian ini ditujukan untuk dapat meningkatkan pengetahuan dan kepedulian para pemuda di Desa Gondang terhadap berbagai potensi desa secara khusus dan mendorong peningkatan partisipasi pemuda dalam pembangunan, secara umum. Hasil dari program pengabdian masyarakat ini adalah teridentifikasinya potensi desa yakni terkait dengan lingkungan yakni pengelolaan sampah. Pemuda memiliki kesadaran untuk terlibat dalam pembangunan desa melalui program pengelolaan sampah dengan adanya rencana jangka menengah dengan mendirikan bank sampah dan jangka panjang dengan mengelola desa wisata. Hambatan atau tantangan yang dihadapi dalam proses pembangunan perdesaan yakni kesadaran masyarakat desa setempat tentang kebersihan lingkungan yang masih kurang dan Karang Taruna Desa Gondang yang kurang aktif terlebih pasca Gempa Lombok tahun 2018 lalu.
\end{abstract}

Korespondensi: mayaatrikomalasari@unram.ac.id

\section{PENDAHULUAN}

Pemuda adalah salah satu kompenen penting dalam struktur warga negara di seluruh dunia. Begitupun yang terjadi di Indonesia. Pemuda memiliki tempat dan peran tersendiri. Lebih khusus, bahkan di Indonesia selalu diidentikan dengan pemuda sebagai pemegang tonggak estafet kepemimpinan selanjutnya. Atau terdapat istilah yang sangat populer bahwa pemuda adalah masa depan suatu bangsa. Pemuda selalu diidentikan sebagai generasi penerus suatu bangsa. Hal ini terkandung adanya dua sudut pandang yang berbeda. Satu sisi hal tersebut merupakan tantangan yang harus ditaklukan pemuda. Namun di sisi lain hal tersebut dapat menjelma menjadi suatu beban bagi pemuda jika tidak mampu menghadapinya.

Dalam era ini, dimana globalisasi menyebar ke seluruh dunia tanpa kecuali termasuk pula masuk di perdesaan. Berbagai hal dalam aspek kehidupan pun banyak yang mengalami perubahan. Termasuk persoalan tentang peluang kerja di era globalisasi. Era globalisasi membuat berbagai peluang kerja baru lahir seperti seputar peluang kerja bidang teknologi informasi. Namun di saat yang sama globalisasi juga berdampak pada tingkat persaingan 
mendapatkan berbagai peluang kerja yang makin tinggi dan sulit. Hal ini merupakan tantangan sekaligus hambatan yang dialami pemuda dewasa ini. Terlebih pemuda merupakan penduduk dengan karakteristik tertentu yang khas.

Pemuda menempati posisi yang cukup dilematis. Pemuda merupakan elemen yang penting dan krusial bagi keberlanjutan sebuah bangsa, namun di sisi yang lain, pemuda juga menjadi subjek yang relatif termarginalkan sebagai dampak dari infiltrasi neoliberalisme, ketidakpedulian pemerintah dan kesenjangan sosial yang semakin tajam termasuk sebagai akibat dari ketidakadilan global (Sutopo, 2016). Dampak dari kondisi tersebut ialah bisa jadi pemuda menjadi tidak banyak dilibatkan dalam berbagai mekanisme pengambilan keputusan. Selain itu, berbagai kebijakan yang dihasilkan pun jarang yang mengakomodir dan memperhatikan kondisi yang benar- benar dialami oleh pemuda.

Terdapat kondisi khas yang dialami pemuda dan yang membedakannnya dengan golongan penduduk lainnya yakni mengalami proses atau masa transisi. Setidaknya terdapat masa transisi menuju dunia kerja adalah hal yang paling kentara. Sering dilihat dalam perspektif atau pendekatan youth as an action (Jones, 2009) melihat transisi pemuda merupakan fase untuk mengeksplorasi identitas; pemuda bebas untuk menggali, bereksperimen, dan akhirnya memilih jalan yang sesuai dengan keinginannya serta berstrategi untuk memperoleh peluang yang lebih baik untuk masa depannya (Sutopo, 2013).

Suatu proses layaknya pembangunan merupakan suatu perjalanan panjang dan kompleks. Proses tersebut menyangkut berabagai aspek penting dalam kehidupan serta melibatkan semua pihak dalam masyarakat tanpa kecuali. Idealnya dalam pembangunan hendaknya mampu membuat seluruh anggota masyarakat dapat terlibat, punya peran atau dengan kata lain berpartisipasi. Kenyataan yang terjadi masih belum sesuai yang diharapkan. Partisipasi masyarakat pada pembangunan masih kurang atau rendah (Latif, 2014; Purnamasari, 2008).

Partisipasi masyarakat yang rendah menjadi masalah mendasar dalam proses pembangunan. Hal ini disebabkan partisipasi menjadi tonggak dalam langkah awal proses panjang pembangunan. Tanpa partisipasi yang tinggi dan maksimal seakan pembangunan kehilangan arti. Karena bagaimanapun masyarakat dalam proses pembangunan ialah subyek itu sendiri. Dari mereka hendaknya proses perubahan dan pembangunan itu diawali. Peran serta atau partisipasi seluruh anggota masyarakat adalah mutlak diperlukan dalam pembangunan, termasuk dalam pembangunan desa.

Pembanguanan desa memerlukan partisipasi seluruh anggota masyarakat terutama pemuda. Jika keterlibatan atau partisipasi pemuda rendah akan berpengaruh yakni dapat menghambay terhadap proses pembangunan desa. Partisipasi pemuda dalam pembangunan perdesaan sangat penting karena perannya untuk dapat menggali, mengeksplorasi hingga memanfaatkan berbagai potensi desa baik potensi ekologis,ekonomi, sosial dan budaya. Hanya dengan mengetahui, memahami berbagai potensi tersebut maka dapat menunjang pembanguan perdesaan bahkan mampu lahir berbagai peluang kerja yang menjanjikan bagi para pemuda.

Pemberdayaan menjadi kunci untuk mengatasi permasalahan tersebut. Upaya pemberdayaan yang dimaksud ialah kegiatan sosialisasi yang memiliki beberapa fokus dan tujuan. Pertama, untuk meningkatkan pengetahuan pemuda terhadap berbagai potensi desa 
(ekologi, ekonomi, sosial dan budaya) yang ada. Kedua, untuk mendorong adanya kepedulian pemuda terhadap potensi-potensi desa yang ada. Upaya pemberdayaan dilakukan dengan harapan dapat mendorong kepekaan pemuda terhadap potensi-potensi desanya dan dalam jangka panjang hal tersebut dapat berkontribusi terhadap pembangunan desa. Karena pemberdayaan yang dilakukan pun pada akhirnya bermuara pada menciptakan keberdayaan.

\section{METODE KEGIATAN}

Kegiatan pengabdian masyarakat ini dilakukan berdasarkan metode pemberdayaan untuk menuju keberdayaan suatu masyarakat. Dilakukan dengan metode penyuluhan dan diskusi dengan cara Focused Group Discussion (FGD). Kegiatan ini dilakukan melalui beberapa tahap. Berbagai tahap-tahap kegiatan ini meliputi : Pertama ialah melakukan observasi lokasi sekaligus melakukan koordinasi dengan pemerintahan desa setempat, Kedua ialah kegiatan penyuluhan/sosialisasi serta FGD. Penyuluhan/sosialisasi terkait penguatan kelompok/kelembagaan. Dalam penguatan kelembagaan ini diimplementasikan pada kelompok sasaran yakni para pemuda di Desa Gondang. Penguatan kelembagaan pada mereka dilakukan melalui sosialisasi/penyuluhan sekaligus FGD tentang modal sosial. Pelaksaan kegiatan berupa penyampaian materi oleh tim pengabdian masyarakat kemudian dilanjutkan dengan diskusi bersama kelompok sasaran yakni para pemuda Desa Gondang. Peran modal sosial pengabdian ini ditujukan untuk dapat meningkatkan pengetahuan dan kepedulian para pemuda di Desa Gondang terhadap berbagai potensi desa secara khusus dan mendorong peningkatan partisipasi pemuda dalam pembangunan, secara umum.

\section{HASIL DAN PEMBAHASAN}

Peran pemuda dalam pembangunan amatlah jelas dan penting. Pemuda kerap diidentikan dengan istilah generasi penerus bangsa. Dalam proses pembangunan bangsa, pemuda merupakan kekuatan moral, kontrol sosial, dan agen perubahan (agent of change) sebagai perwujudan dari fungsi, peran, karakteristik, dan kedudukannya yang strategis dalam pembangunan nasional (Statistik Pemuda Indonesia, 2011) .

Peran pemuda dalam pembangunan ditunjukkan dengan kedudukan mereka sebagai generasi penerus bangsa. Hal ini tidak terlepas dengan keterkaitannya dengan definisi pemuda itu sendiri. Pemuda atau youth dalam Bahasa Inggris dapat dimaknai sebagai kelompok orang (seperti anak/child dan dewasa adult) dan 'youth' (kepemudaan) sebagai keadaan berusia muda (seperti 'masa kanakkanak'/' childhood' dan 'usia dewasa'/adulthood) (White, 2012). Pemuda sendiri merupakan bagian dari penduduk atau warga negara yang memiliki karakteristik tertentu. Menurut Undang-Undang RI No. 40 Tahun 2009 tentang Kepemudaan, pengertian Pemuda adalah warga negara Indonesia yang memasuki periode penting pertumbuhan dan perkembangan yang berusia 16 (enam belas) sampai 30 (tiga puluh) tahun.

Pemuda, merupakan kekayaan Sumber Daya Manusia (SDM) potensial bagi tiap negara dan bangsa. Pemuda dengan usia muda usia yang paling produktif dalam diri manusia. Pembahasan tentang kerja dan pemuda sangatlah menarik. Hal ini disebabkan pemuda merupakan aset tenaga kerja sekaligus angkatan kerja itu sendiri. Dengan demikian, peran pemuda dalam pembangunan ialah tampak sebagai aktor atau orang yang terlibat langsung dalam pembangunan sebagai angkatan kerja. Selain itu, pemuda juga dapat 
berperan lebih dari sekedar pelaksana dalam proses pembangunan. Pemuda memliki potensi dan kompetensi sebagai perencana berkat adanya pemikiran dan tindakan-tindakan inovatifnya. Terutama di era saat ini dimana teknologi sangat mendominasi perkembangan semua bidang maka membuka kesempatan pemuda berpartisipasi.

Potensi desa merupakan kekayaan sekaligus kekuatan khas suatu wilayah desa. Secara garis besar potensi desa dapat dibedakan menjadi dua; Pertama adalah potensi fisik yang berupa tanah, air, iklim, lingkungan geografis, binatang ternak, dan sumber daya manusia. Kedua adalah potensi non-fisik berupa masyarakat dengan corak dan interaksinya, lembaga-lembaga sosial, lembaga pendidikan, dan organisasi sosial desa, serta aparatur dan pamong desa.

Potensi sosial desa memiliki peran yang cukup penting dalam pembangunan perdesaan. Layaknya suatu kendaraan seperti mobil maka berbagai spare part seperti roda, ban, mesin, body dan bahan bakar bisa kita ibaratkan sebagai potensi fisik, sementara potensi sosial dianalogikan sebagai chasis nya. Chasis atau sasis ialah kerangka internal yang menjadi dasar untuk produksi suatu objek yang disatukan dengan mesin atau alat elektronik dari objek tersebut. Dalam hal ini, sasis berguna untuk menghubungkan, mengkerangkai dan menyatukan semua spare part mobil agar nantinya bisa bergerak dengan leluasa. Itulah analogi peran potensi sosial seperti sasis pada mobil. Sasis pada mobil yang membuatnya bisa bergerak dengan leluasa inilah yang menunjukkan pula peran modal sosial pada potensi desa.

Dalam potensi sosial desa itu sendiri sudah selayaknya ada. Dengan adanya modal sosial inilah yang akhirnya mampu menjembatani, menghubungkan hingga menguatkan berbagai potensi yang ada di tiap desa. Bagaimanapun besarnya berbagai potensi fisik suatu desa jika tidak ditunjang dengan potensi desa yang kuat maka tidak akan menghasilkan hasil yang maksimal. Oleh karena itu, potensi-potensi desa agar mampu dikembangkan menuju kesejahteraan masyarakat perlu penguatan modal sosial yang merupakan bagian dari potensi sosial desa.

Modal sosial merupakan segala sesuatu hal yang berkaitan dengan kerja sama dalam masyarakat atau bangsa untuk mencapai kapasitas hidup yang lebih baik, ditopang oleh nilai-nilai dan norma yang menjadi unsur-unsur utamanya seperti trust (rasa saling mempercayai), keimbal-balikan, aturan-aturan kolektif dalam suatu masyarakat atau bangsa dan sejenisnya (Hasbullah, 2006). Modal sosial juga dimaknai sebagai sejumlah sumber daya aktual atau maya, yang berkumpul pada seseorang individu atau kelompok karena memiliki jaringan tahan lama berupa hubungan timbal-balik yang sedikit banyak terinstitusionalisasikan (Field, 2010). Dari penjelasan tersebut diketahui bahwa modal sosial sangat terkait dengan proses kerja sama.

Modal sosial merupakan suatu hubungan-hubungan yang tercipta karena adanya norma-norma tertentu dan keadaan tertentu. Dalam prosesnya modal sosial tersebut juga akan menghasilkan kepercayaan (trust), jaringan (network), dan nilai-nilai/norma resiprositas (reciprocity) yang mempermudah terjalinya kerjasama antara orang yang terlibat.

Kegiatan pengabdian masyarakat ini dilakukan pada hari Minggu, 18 Agustus 2019. Tempat pelaksanaan kegiatan ialah Aula Desa Gondang. Peserta atau kelompok sasaran ialah para pemuda desa setempat. Hadir pula perwakilan dari Desa Gondang yang diwakili 
oleh Sekretaris Desa Bapak Isnaini yang sekaligus memberikan sambutan.

Kegiatan yang dilakukan berupa sosialisasi/penyuluhan yang dilakukan oleh tim pengabdian masyarakat. Berbagai materi yang disampaikan antaralain: 1) Mengenal Modal Sosial, 2) Pemuda dan Pembangunan, 3) Modal Sosial dan Potensi desa dan 4) Modal Sosial Pemuda dalam Pembangunan Desa. Setelah dipaparkan berbagai materi tersebut dilanjutkan dengan FGD dengan para peserta yakni pemuda yang hadir. Diskusi dilakukan dengan interakatif dan terdapat pula proses tanya jawab antara tim pengabdian masyarakat dengan para pemuda Desa Gondang.

Berdasarkan kegiatan pengabdian masyarakat yang telah diadakan terhadap para pemuda di Desa Gondang, Kecamatan Gangga, Kabupaten Lombok Utara diperoleh beberapa hal penting sebagai hasilnya. Dari hasil FGD berhasil menggali potensi Desa Gondang yakni terkait potensi lingkungan. Terdapat potensi desa yang menjanjikan namun belum dikelola secara maksimal yakni terkait pengelolaan sampah. Sudah terdapat kelompok pemuda yang merintis upaya pengeloaan sampah yakni kelompok sadar sampah dari Dusun Karang Kerem. Mereka telah melakukan kegiatan pengelolaan sampah dengan cara mengumpulkan dan memisahkan sampah dari tiap rumah tangga di dusun tersebut. Namun begitu mereka belum sampai pada mengelola, mendaur ulang recyle sampahsampah tersebut. Hal ini disebabkan kurangnya pengetahuan mereka terhadap pengelolaan terutama mengolah sampah menjadi barang baru dengan fungsi lain seperti menjadi kerajinan atau cinderamata. Oleh karena itu, pemuda memiliki ide

Hasil FGD juga menunjukkan adanya kesadaran dan kemauan pemuda untuk berpartisipasi dalam pembangunan desa terutama terkait dengan lingkungan. Hal ini terlihat dari pemuda kelompok sadar sampah yang memiliki tujuan atau rencana ke depan yakni dengan adanya program jangka menengah dan jangka panjang. Untuk program jangka menengah ialah mendirikan dan mengelola bank sampah dan program jangka panjang atau untuk kedepannya ingin menjadikan Desa Gondang menjadi desa ecowisata dimana potensi desa hijau kedepannya diharapkan mampu menjadi daya tarik wisata tersendiri.

Hasil FGD menunujukkan pula berbagai masalah atau hambatan yang dihadapi dalam kaitannya dengan pembangunan desa. Pertama, kesadaran masyarakat desa setempat tentang kebersihan lingkungan yang masih kurang. Belum banyak masyarakat yang memliki kesadaran dalam pengelolaan sampah. Masih adanya kebiasaan membuang sampah sembarang menjadi tantangan tersendiri. Selain itu, masih terdapat permasalah sanitasi yang mendasar yakni terkait masih terdapat masyarakat yang belum memiliki tempat khusus untuk mandi cuci kakus (MCK) khususnya Kedua, terkait dengan kurang aktifnya kegiatan pemuda yakni dalam Karang Taruna, terlebih pasca gempa kegiatannya menjadi tidak terlalu aktif. Disamping disebabkan karena faktor ketua Karang Taruna yang juga mahasiswa menempuh pendidikan Perguruan Tinggi di Mataram, juga disebabkan oleh faktor anggaran. Anggaran atau dana yang ada di desa memang difokuskan pada rehabilitasi pasca gempa, mengingat Desa Gondang merupakan salah satu desa terdampak Gempa Lombok 2018 silam. 


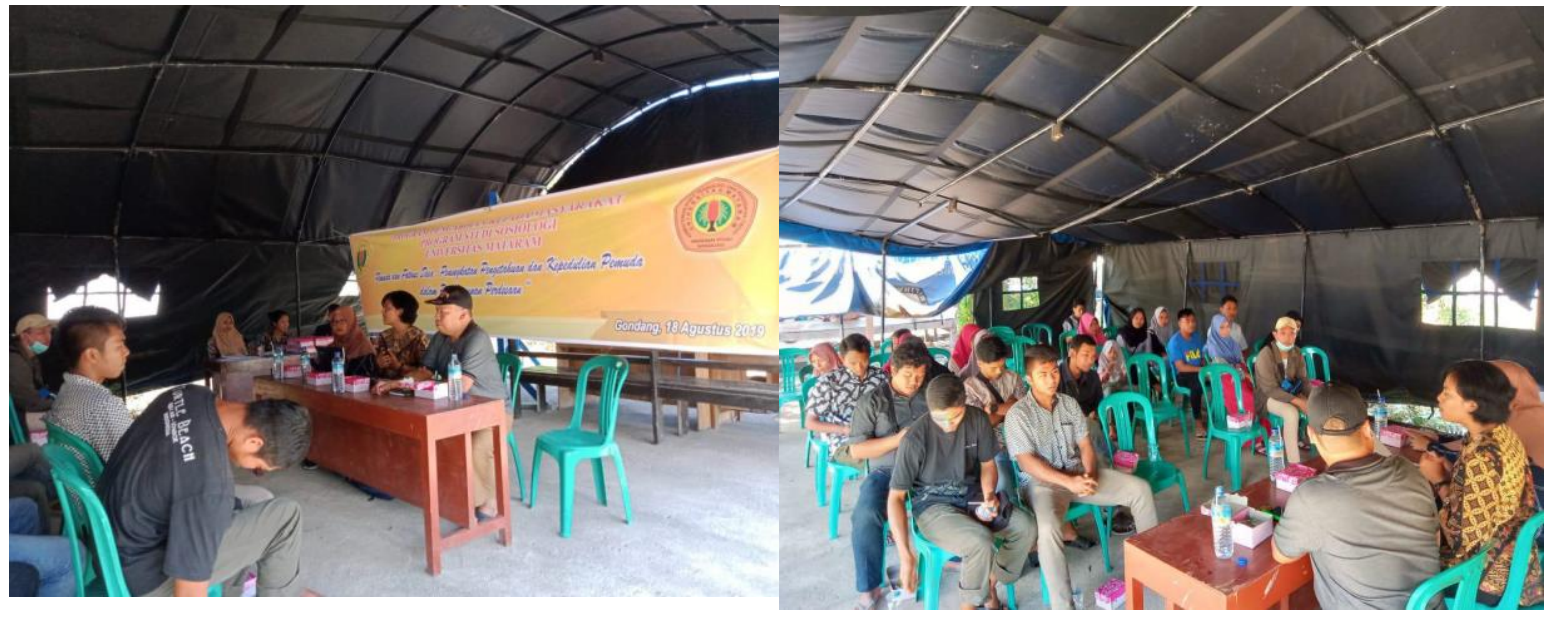

Gambar 1. Kegiatan Pengabdian Masyarakat di Desa Gondang

\section{KESIMPULAN DAN SARAN}

Dari kegiatan ini diperoleh beberapa hasil penting. Pemuda di Desa Gondang,Kecamatan Gangga, Kabupaten Lombok Utara mampu mengidentifikasi potensi desa. Potensi tersebut ialah terkait dengan lingkungan yakni pengelolaan sampah. Telah terdapat kelompok pemuda pengelola sampah di salah satu dusun yakni di Desa Karang Kerem. Selain itu pemuda telah berhasil memiliki kesadaran untuk terlibat dalam pembangunan desa melalui program pengelolaan sampah dengan adanya rencana jangka menengah dengan mendirikan bank sampah dan jangka panjang dengan mengelola desa wisata. Pemuda juga berhasil mengidentifikasi hambatan atau tantangan yang mereka hadapi dalam proses pembangunan perdesaan yakni kesadaran masyarakat desa setempat tentang kebersihan lingkungan yang masih kurang dan Karang Taruna Desa Gondang yang kurang aktif terlebih pasca Gempa Lombok tahun 2018 lalu.

Saran untuk kegiatan pengabdian masyarakat yang dapat dilakukan selanjutnya bisa fokus menyasar dengan mengadakan pelatihan dan pengadaan sarana pengelolaan dan pengolahan sampah.

\section{UCAPAN TERIMA KASIH}

Penulis mengucapkan terima kasih kepada Lembaga Penelitian dan Pengabdian Masyarakat (LPPM) Universitas Mataram yang telah memberi dukungan finansial terhadap pengabdian ini. Penulis juga mengucapkan terimakasih pada Pemerintah Desa serta Masyarakat, Pemuda Desa Gondang yang telah mengizinkan dan menjadi tempat berlangsungnya kegiatan pengabdian masyarakat ini.

\section{DAFTAR PUSTAKA}

BPS. 2011. Statistik Pemuda Indonesia 2011. Jakarta :Badan Pusat Statistik Field, J. 2010. Modal Sosial . Kreasi Wacana: Yogyakarta

Hasbullah, J. 2006. Social Capital: Menuju Keunggulan Budaya Manusia Indonesia. MR-United Press: Jakarta Jones, G. 2009. Youth. Polity Press : Cambridge 
Latif, A. Peran Partisipasi Masyarakat dalam Peningkatan Pembangunan Desa di Kecamatan Posigadan. Madani: Jurnal Pengabdian Ilmiah, Vol. 4 No. 1

Purnamasari, I. 2013. Studi Partisipasi Masyarakat dalam Perencanaan Pembangunan di Kecamatan Cibadak Kabupaten Sukabumi. Disertasi. Program Pascasarjana Universitas Diponegoro

Sutopo, O. R. 2013. Hidup adalah Perjuangan : Strategi Pemuda Yogyakarta dalam Transisi Dunia Pendidikan ke Dunia Kerja”. Jurnal Sosiologi Masyarakat, Vol. 18 No. 2, Juli 2013 : 161-179

Sutopo, O. R. 2016. Agenda Pembangunan Kajian Kepemudaan Indonesia. Jurnal Sosiologi Pendidikan Humanis Volume 1, Nomor 2, Desember 2016 : 161-172

White, B. 2012. Pertanian dan Masalah Generasi: Pemuda Desa, Kesempatan Kerja, dan Masa Depan Pertanian. Jurnal Analisis Sosial Vol. 17 No. 2 